\title{
Spurious hyperkalaemia
}

\author{
M. R. WILLS AND I. D. FRASER \\ From the Department of Clinical Pathology, Bristol Royal Infirmary
}

SYNOPSIS In a patient with acute lymphoblastic leukaemia, the plasma was found to have a potassium level of $10.4 \mathrm{mEq}$./1. Investigations showed that plasma from patients with leukaemia may be found to have falsely high potassium levels because of breakdown of leucocytes between the venepuncture and separation of the plasma.

Plasma from a patient with acute lymphoblastic leukaemia was found to have a potassium level of $10.4 \mathrm{mEq}$./1. The specimen, which was taken into heparin and separated from the red cells within two and a half hours after collection, was unhaemolysed. The patient was not on a high potassium intake, had satisfactory renal function, and lacked any symptoms, signs, or electrocardiographic evidence of hyperkalaemia. Another sample of blood, centrifuged immediately after collection, was found to have a normal potassium level. An investigation was therefore started to determine whether there was an abnormal liberation of potassium in vitro from the formed elements of blood in leukaemic patients.

\section{CASE MATERIAL AND METHODS}

Eleven patients with various forms of leukaemia were studied as shown in Table I.

Two possible causes for the rise in plasma potassium concentration were investigated: (1) delay in separation of the plasma from the cellular fraction and (2) leucocyte fragility.

DELAY IN SEPARATION OF PLASMA Plasma potassium concentration was estimated by flame photometry. A single sample of blood was collected from each patient, with minimal stasis, and divided into two heparin containers. One was centrifuged within two minutes of collection; the other specimen was left standing at room temperature for two hours before the plasma was separated. In the patient suffering from acute lymphoblastic leukaemia the plasma and leucocyte layers were aspirated from a further specimen which was separated within two minutes of collection; these two fractions were allowed to stand in contact for two hours at room temperature, before centrifugation.

In normal control subjects, heparinized blood was collected with minimal stasis and was left at room temperature during which time aliquots were removed and centrifuged at hourly intervals for five hours. Thereafter the blood was stored at $4^{\circ} \mathrm{C}$. and further aliquots were centrifuged at 24,36 , and 48 hours.

Received for publication 10 January 1964
LEUCOCYTE FRAGILITY At the same time as the blood was collected for the potassium studies, a sample was also taken into a sequestrene container. This sample was left at room temperature for $\mathbf{3 0}$ minutes to allow the layers to settle partially; the leucocyte-rich plasma was then carefully aspirated through a wide-bore needle and a mechanical leucocyte fragility test was carried out in the following way. Leucocyte-rich plasma, $2 \mathrm{ml}$, was pipetted into a tube containing four small glass beads. The tube was then put into a mechanical rotator. At the start and half-hourly intervals thereafter for two hours a total leucocyte count was carried out and the number of degenerate (smear) cells was estimated both in a counting chamber and as a separate wet preparation.

\section{RESULTS AND CONCLUSIONS}

Blood from normal patients showed no significant rise in plasma potassium concentration during five hours standing at room temperature, though further storage at $4^{\circ} \mathrm{C}$. resulted in considerable increase (Fig. 1).

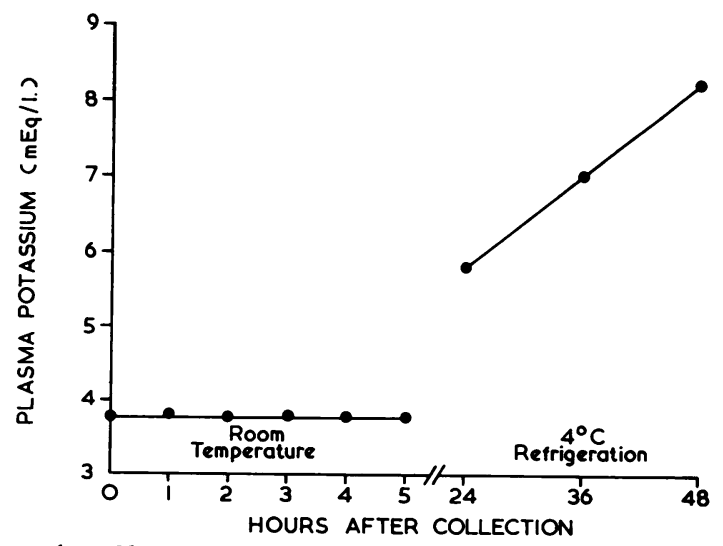

FIG. 1. Changes in plasma potassium after storage of whole blood at room temperature and at $4^{\circ} \mathrm{C}$. refrigeration in normal subjects. 
TABLE I

PLASMA POTASSIUM LEVELS AND CELL COUNTS IN CASES AND CONTROLS

Case No. Type of Leukaemia

$\begin{array}{llll}\text { Plasma Potassium Level (mEq./l.) } & & \text { Total and (Smear) Cell Count (c.mm.) } \\ \begin{array}{lll}\text { Two-minute } & \text { Two-hour } \\ \text { Separation } & \text { Separation }\end{array} & & \text { Before Rotation } & \text { After Two Hours' Rotation } \\ \end{array}$

\begin{tabular}{|c|c|c|c|c|c|}
\hline $\begin{array}{r}1 \\
2 \\
3 \\
4 \\
5 \\
6 \\
7 \\
8 \\
9 \\
10 \\
11\end{array}$ & $\begin{array}{l}\text { Acute lymphoblastic } \\
\text { Acute monocytic } \\
\text { Acute monocytic } \\
\text { Acute myeloblastic } \\
\text { Acute nyeloblastic } \\
\text { Chronic lymphatic } \\
\text { Chronic lymphatic } \\
\text { Chronic lymphatic } \\
\text { Chronic lymphatic } \\
\text { Chronic lymphatic } \\
\text { Chronic myeloid } \\
11 \text { normal (average) }\end{array}$ & $\begin{array}{l}2 \cdot 7 \\
5 \cdot 8 \\
4 \cdot 3 \\
4 \cdot 3 \\
4 \cdot 1 \\
4 \cdot 6 \\
4 \cdot 0 \\
4 \cdot 9 \\
4 \cdot 8 \\
4 \cdot 5 \\
3 \cdot 5\end{array}$ & $\begin{array}{l}8 \cdot 2 \\
5 \cdot 8 \\
3 \cdot 8 \\
3 \cdot 8 \\
4 \cdot 0 \\
4 \cdot 5 \\
5 \cdot 1 \\
4 \cdot 9 \\
4 \cdot 8 \\
4 \cdot 3 \\
3 \cdot 9\end{array}$ & $\begin{array}{c}630,000(46,000) \\
21,000(630) \\
136,000(2,720) \\
635,000(3,175) \\
322,000(320) \\
360,000(1,400) \\
200,000(14,000) \\
21,000(1,300) \\
115,000(3,100) \\
70,000(4,900) \\
747,000(1,500) \\
12,000(\mathrm{Nil})\end{array}$ & $\begin{array}{c}585,000(181,900) \\
17,100(700) \\
131,000(5,240) \\
610,000(2,500) \\
301,000(300) \\
396,000(3,000) \\
184,000(28,400) \\
17,700(1,500) \\
111,000(6,000) \\
65,000(5,600) \\
801,000(1,500) \\
10,300(20)\end{array}$ \\
\hline
\end{tabular}

Table I shows that the blood from leukaemic patients showed a significant rise over a two-hour period at room temperature in only two cases (cases 1 and 7). These same two patients were also the only ones who showed an increase in smear cell count of more than $3,000 / \mathrm{c} . \mathrm{mm}$. One of them (case 1), suffering from acute lymphoblastic leukaemia, showed a rise in plasma potassium of $5.5 \mathrm{mEq}$. $/ 1$. associated with an increased smear cell count of $135,900 /$ c.mm., and in the other (case 7), a case of chronic lymphatic leukaemia, the rise in plasma potassium was $1.1 \mathrm{mEq} . / 1$. and that of the smear cell count $13,600 /$ c.mm.

It seems, therefore, that plasma from patients with leukaemia may be found to have falsely high potassium levels because of breakdown of leucocytes between the venepuncture and the separation of the plasma. That the potassium is released from leucocytes rather than red cells is supported by a single experiment on leucocyte-rich plasma from case 1 , which showed a rise of plasma potassium from 2.5 to $5.9 \mathrm{mEq}$./1. over two hours at room temperature.

An elevation in serum potassium concentration due to release of potassium from platelets during clotting was described by Hartmann, Auditore, and 음 Jackson (1958) in a series of patients with thrombo- $\rightarrow$ cytosis. In the cases they described, the platelet $z$

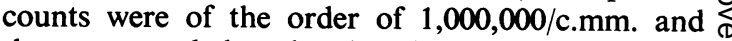
they suggested that the elevation in potassium was due to breakdown of the platelets in the clotting $\underset{\mathbb{\Phi}}{-}$ process; they demonstrated that potassium was not released from platelets during incubation of unclotted plasma for a period of one hour. In our cases, the platelet counts were from 25,000 to $60,000 / \mathrm{c} . \mathrm{mm}$. in case 1 and from 95,000 to $140,000 / \mathrm{c} . \mathrm{mm}$. in case 7; in no case was coagulation allowed to occur, so that such a mechanism would not appear to be operating in these cases.

We conclude that blood from patients with leukaemia should be centrifuged immediately if plasma potassium levels are to be estimated.

We are indebted to Drs. G. K. McGowan and A. B. Raper for their helpful advice and criticism in the preparation of this paper.

\section{REFERENCE}

Hartmann, R. C., Auditore, J. V., and Jackson, D. P. (1958). J. clin. Invest., 37, 699. 